\title{
USULAN MODEL PENGELOLAAN SUMBERDAYA BUDAYA: PEMIKIRAN BERDASARKAN KASUS-KASUS DI KALIMANTAN
}

\author{
Wasita* \\ BalaiArkeologi Banjarmasin, Jalan Gotong Royong II, RT 03/06, Banjarbaru 70711, Kalimantan Selatan; \\ Telepon (0511) 4781716; Facsimile (0511) 4781716
}

\begin{abstract}
Abstrak. Tulisan ini membahas sejumlah kasus pengelolaan sumber daya budaya di Kalimantan yang tidak sesuai dengan Undang-Undang Cagar Budaya dan menyusun gagasan tentang sebuah model pelestarian cagar budaya berbasis pemanfaatan. Upaya tersebut dilakukan dengan mengidentifkasi dan mengevaluasi implemantasi peraturan dan kegiatan pelestarian yang telah dilakukan oleh para pemangku kepentingan kebudayaan di Kalimantan. Hasil evaluasi menunjukkan adanya standar ganda penerapan peraturan pelestarian cagar budaya di Kalimantan. Selain itu, persepsi subyektif-afektif dan kepentingan stakholders ternyata juga mempengaruhi tujuan dan aktivitas pengelolaan cagar budaya. Dengan demikian, model pelestarian yang diajukan adalah menginduksikan perspektif pemanfaatan cagar budaya dalam konteks sistem, yang melibatkan masyarakat secara aktif dalam aktivitas pelestariannya, serta memposisikan instansi arkeologi sebagai fasilitator, mediator, dan pengawas pelestarian cagar budaya.
\end{abstract}

Kata kunci: cagar budaya, pelestarian, undang-undang, evaluasi, sumber daya budaya, model pengelolaan, konteks sistem

Abstract. CULTURAL RESOURCES MANAGEMENT MODEL: (CASE STUDY IN KALIMANTAN). This paper discusses a number of cases of cultural resources management in Kalimantan, which did not comply with the Heritage Act and formulate ideas of a benefitting-based model of cultural heritage preservation. Such efforts were conducted by identifying and evaluating implemented rules and conservation activities, which have been undertaken by the stakeholders of culture in Kalimantan. The evaluation shows that a double-standard regulation implementation of cultural heritage conservation in Kalimantan have had occurred. Furthermore, apparently, subjective-affective perceptions and interests of stakholders have had also affected the objectives and activities of cultural heritage management. Thus, the proposed preservation model is built by inducing cultural heritage benefitting-perspective in the system-context, which actively involving communities in conservation activities, as well as positioning archaeological offices as facilitators, mediators, and cultural heritage preservation supervisors.

Keywords: cultural preservation, conservation, legislation, evaluation, cultural resources, model management, system context

* Penulis adalah Peneliti Madya pada Balai Arkeologi Banjarmasin, email: wasita6@yahoo.com. 
Usulan Model Pengelolaan Sumberdaya Budaya:

Pemikiran Berdasarkan Kasus-kasus di Kalimantan 170-194

\section{A. Pendahuluan}

1. Latar Belakang dan Permasalahan

Keberadaan sumberdaya budaya (SDB) yang ada di Indonesia telah diatur sejak zaman pemerintah kolonial Belanda, yaitu dengan Monumenten Ordonantie Stb. 238 Tahun 1931. Monumenten tersebut memuat aturan tentang perlindungan dan pengamanan. Menurut Ida Bagus Sapta Jaya $(2011,4)$ pengertian pengamanan dalam Monumenten tersebut tidak dapat dipisahkan dengan pendokumentasian, penelitian, pemugaran, pemeliharaan, dan perlindungan.

Di sisi lain, pemugaran, pemeliharaan, dan perlindungan tidak ubahnya merupakan pelestarian. Sementara itu, dalam UU No. 5 tahun 1992 dan No. 11 Tahun 2010, pelestarian disebut dengan jelas. Ini mengindikasikan bahwa pengelolaan warisan purbakala untuk memperoleh pencapaian maksimal merupakan tujuan yang ditargetkan. Dalam hal ini, Undang-undang No 11 tahun 2010 merupakan perubahan terhadap Undang-undang No 5 tahun 1992. Perubahan dimaksudkan sebagai upaya penyempurnaan. Saya kira ini merupakan tindakan untuk lebih memaksimalkan perolehan atas penerapan undang-undang baru tersebut.

Di samping itu, secara akademis sudah banyak tulisan yang membahas pengelolaan SDB. Tulisan tersebut antara Iain mengandung pemikiran untuk penyempurnaan atau evaluasi dalam bentuk terapan (implementasi). Sampai di sini terlihat bahwa aturan pengelolaan SDB telah ada dan evaluasi telah dilakukan. Oleh karena itu, pemikiran yang tertuang dalam tulisan ini merupakan evaluasi terutama pada celahcelah yang masih menyisakan bagian yang masih berlubang dan belum tergarap. Maksudnya, ikut memberikan evaluasi dengan mencoba menembus ke bagian-bagian kecil yang belum disentuh pada evaluasi sebelumnya, tetapi merupakan bagian yang kurang dan jika diperbaiki bisa dirasakan manfaatnya untuk diimplementasikan dalam praktek pelestarian di lapangan.

Mengapa itu diperlukan, sebab kenyataan di lapangan menunjukkan masih ada permasalahan dalam implementasi pelestarian di Kalimantan. Hal ini ditunjukkan oleh adanya situs dan SDB yang tidak kena dalam sasaran pelestariannya. Buktinya, dapat dilihat di Sanga Sanga terutama di situs kolonial dengan temuan arsitektur rumah yang banyak dan penting bagi sejarah bangsa ini. Ironisnya, sebagian besar temuan tersebut belum terdaftar sebagai cagar budaya. Ini sedikit banyak berdampak pada program pelestariannya.

Di tempat lain, misalnya di Kalimantan Selatan, antara lain terdapat makam Sultan Suriansyah (Banjarmasin), Datu Sanggul (Tapin), serta Candi Agung. Ketiga situs tersebut telah masuk sebagai cagar budaya. Namun dalam prakteknya, pengelolaan terhadap ketiganya kurang maksimal atau paling tidak, pengelolaan dilakukan dengan prinsip-prinsip yang kurang mengena dalam kaidah kepurbakalaan. Misalnya, pengelolaan Candi Agung lebih menekankan urusan keindahan daripada sejarahnya. Demikian juga di kedua makam tersebut, lebih kental mistiknya daripada historisnya.

Di Kalimantan Barat antara lain terdapat bangunan yang diduga sebagai candi yang ada di Negeri Baru, Ketapang. Temuan tersebut masih merupakan dugaan karena 
Usulan Model Pengelolaan Sumberdaya Budaya:

sejauh ini atribut kunci untuk bisa disebut sebagai candi, belum ditemukan. Namun demikian, temuan ini merupakan hal yang monumental untuk wilayah Kalimantan Barat sehingga penting sekali untuk diungkap lebih lanjut. Guna kepentingan tersebut, pemilik tanah tempat situs berada meminta kepada Dinas Kebudayaan, Pariwisata, Pemuda, dan Olahraga Kabupaten untuk segera membebaskan lahan tersebut, sehingga mereka tidak mengalami banyak kerugian jika penelitian terus berlangsung setiap tahunnya. Aspirasi ini ditanggapi oleh pihak Dinas yang kemudian mengajukan permohonan pembebasan tanah. Ternyata upaya ini dialihkan dalam pengambilan keputusan di DPRD Tingkat II. Anggaran pembebasan tanah tetap ada dan dilakukan untuk anggaran dinas yang sama tetapi untuk bidang yang berbeda, yaitu untuk pembebasan tanah guna pembangunan gedung olah raga. Ini merupakan visualitas bahwa urusan kepurbakalaan menempati urutan kepentingan yang rendah dengan prioritas bagian bawah.

Semua pembicaraan di atas adalah fenomena yang terjadi dan terkait dengan pemahaman Undang-undang Cagar Budaya. Di sisi lain, masih ada juga evaluasi-evaluasi dalam bidang pelestarian yang dilakukan oleh para ahli. Evaluasi tersebut berada dalam tataran implementasi agar pelestarian lebih tepat sasaran. Namun, pada beberapa situs di Kalimantan (seperti di atas), tampak masih ada yang salah dalam pengelolaannya. Oleh karena itu, dalam kesempatan ini akan dilakukan evaluasi di tingkat implementasi yang diharapkan dapat memberi kontribusi terhadap pengelolaan SDB, terutama di Kalimantan. Menindaklanjuti maksud di atas, maka permasalahan yang diangkat dalam tulisan ini adalah bagaimanakah model pengelolaan yang diperlukan agar diperoleh hasil pelestarian yang maksimal?

\section{Tujuan dan Metode}

Tulisan ini dimaksudkan untuk mendapatkan model pelestarian yang tepat dengan perolehan yang maksimal. Guna meraih hal tersebut maka kegiatan yang dilakukan adalah mencoba melihat aturan dan evaluasi yang pernah dilakukan yang sejauh ini diketahui penulis. Selanjutnya, model ideal tersebut dicoba dilihat kesesuaiannya dengan implementasi yang telah dilakukan terhadap cagar budaya yang ada di Kalimantan. Jika misalnya tidak berjalan, maka hal tersebut harus dilihat pada bagian mana masalahnya. Dengan demikian, akan dicoba diterapkan model pengelolaan yang ada dengan kenyataan di lapangan. Cara ini diharapkan akan diperoleh pengetahuan letak permasalahan dan dicoba dilakukan evaluasi untuk melakukan perbaikan. Sementara itu, metode yang digunakan adalah observasi dan wawancara.

\section{Tinjauan Pustaka}

Sejauh ini implementasi pengelolaan sumberdaya budaya masih sering menemui pemasalahan. Bukti di lapangan yang memang menunjukkan adanya konflik tersebut. Biasanya konflik terjadi antara masyarakat sebagai pemangku kepentingan dengan pihak kepurbakalaan yang diwakili oleh pemerintah dengan aparat yang mengurusi bidang tersebut. Jika diperhatikan, permasalahan tersebut bersumber pada tiga hal, yaitu persepsi dan kepentingan stakeholder, tujuan pengelolaan (rambu- 
Usulan Model Pengelolaan Sumberdaya Budaya:

Pemikiran Berdasarkan Kasus-kasus di Kalimantan 170-194

rambu) arkeologi, dan konteks sistem. Dengan demikian, sebenarnya yang harus dikelola adalah tiga komponen tersebut. Dalam hal ini, pengelolaan perlu konteks sistem yang mendukung pelestarian, namun menguntungkan para pemangku kepentingan dan tidak melanggar rambu-rambu pengelolaan.

Seperti inikah pemikiran beberapa ahli yang pernah melakukan evaluasi atas model pelaksanaan pelestarian untuk diterapkan dalam beberapa situs kita. Mendasarkan pada konsep pemanfaatan, Donald G. Macleod dengan konsep peddle or perish kurang lebih menyebutkan bahwa perlindungan tinggalan arkeologi yang efektif adalah yang berdasarkan pemanfaatan (Riyanto 2008, 49). Dalam upaya pemanfaatan oleh masyarakat, hendaknya arkeolog tidak menjadi legislator ataupun fasilitator. Dalam tulisannya yang berjudul Reposisi Arkeologi dalam Era Global, Daud Aris Tanudirdjo $(2000,19)$ mengharapkan agar arkeolog mengubah posisinya dari fasilitator menjadi mediator, yaitu menjadi perantara masa lampau dan masa kini. Dalam tulisannya yang lain, Daud Aris Tanudirdjo $(2004,6)$ menyebutkan bahwa perlindungan yang berazaskan pemanfaatan dilakukan dengan cara memasukkan tinggalan-tinggalan arkeologi ke dalam konteks sistem. Konteks sistem adalah lingkungan budaya yang masih berlangsung dalam suatu tata kehidupan masyarakat. Oleh karena itu, dalam konteks ini sumberdaya budaya masih berperan aktif dan dipergunakan oleh masyarakat (Schiffer 1976 dalam Noerwidi 2007, 87). Tampaknya pola pemikiran ini didasarkan pada logika bahwa benda arkeologi yang dimanfaatkan oleh masyarakat, dalam prakteknya akan dilindungi oleh penggunanya, yaitu masyarakat itu sendiri.

Bambang Sulistyanto (2011a) dalam tulisannya, Konflik dalam Pengelolaan Sumberdaya Budaya menyebutkan adanya realitas konflik tersebut. Pada akhir tulisannya, ia menyimpulkan bahwa untuk menghindari terjadinya konflik yang terus-menerus, yang perlu dilakukan adalah penanggungjawab pelestarian benda cagar budaya bertindak sebagai steward. Maksudnya, mereka harus menyadari kedudukannya hanya sebagai penjaga dan pengelola yang sebenarnya bukan miliknya. Secara profesional, para pengelola harus bertanggung jawab terhadap pemanfaatan dan pelestarian, namun dalam pelaksanaannya harus selalu ingat bahwa aset yang dikelola itu bukan miliknya. Mereka dituntut lebih banyak melihat, mendengar dan merasakan kemauan, kepentingan pemilik sumberdaya itu sendiri.

Tulisan di atas tampaknya menekankan adanya keterlibatan aktif masyarakat. Agar masyarakat dapat terlibat aktif, dalam kesempatan yang berbeda Bambang Sulistyanto (2011b) mengusulkan agar dilakukan pemberdayaan terhadap mereka. Menurutnya, pemberdayaan masyarakat pada hakekatnya adalah upaya untuk melestarikan situs. Pemberdayaan dapat dilakukan dengan mempedulikan masyarakat di sekitar situs, untuk dapat terlibat secara penuh dalam pengelolaan warisan budaya. Pemberdayaan masyarakat di sekitar situs, mempunyai keuntungan bagi kedua belah pihak, yaitu pengelola dan masyarakat itu sendiri. Pihak pengelola, yakni pemerintah (pusat) ataupun pemerintah daerah (otonom) dalam upaya pelestarian memperoleh dukungan dari masyarakat, karena masyarakat dibutuhkan 
Usulan Model Pengelolaan Sumberdaya Budaya:

peran sertanya dalam pengelolaan warisan budaya. Sebaliknya, masyarakat juga memperoleh keuntungan, baik moril maupun materiil, karena warisan budaya dapat memberikan kontribusi yang dapat meningkatkan taraf perekonomiannya. Apabila masyarakat sudah dapat bertindak sebagai "pelindung" dan "penjaga" situs yang muncul dari kesadaran sendiri, hal tersebut merupakan upaya perlindungan dan pelestarian yang paling efektif dan efisien.

Dari tulisan yang berbeda, Bambang Sulistyanto (2009) tentang Warisan Dunia Situs Sangiran: Persepsi Menurut Penduduk Sangiran, berhasil ditunjukkan bahwa terdapat perbedaan persepsi antara penduduk Sangiran dengan pemerintah. Bagi pemerintah, Situs Sangiran merupakan wilayah cagar budaya penghasil fosil yang keberadaannya sangat langka di dunia sehingga perlu dijaga dan dilindungi kelestariannya. Sementara bagi penduduk, daerah perbukitan Sangiran dengan seluruh isinya adalah tanah warisan leluhurnya, di mana anak-cucunya berhak mendayagunakannya untuk berbagai kepentingan hidupnya. Bagi penduduk, pemaknaan tersebut lebih bersifat praktis. Berdasarkan atas persepsi yang demikian, Bambang Sulistyanto kemudian menyimpulkan untuk urusan pelestarian situs, yang harus dilakukan pemerintah adalah melibatkan masyarakat, khususnya penduduk setempat mulai dari perencanaan program, pelaksanaan, hingga pengevaluasiannya.

Sementara itu, Wasita (2011a, 17) mengusulkan agar pelestarian tidak hanya berhenti pada upaya memasukkan tinggalan arkeologi dalam konteks sistem, tetapi juga dilanjutkan dengan upaya-upaya untuk mendukung terjadinya konteks sistem yang mendukung pelestarian. Untuk tujuan tersebut diusulkan adanya perspektif dalam pemanfaatan yang tidak sekedar memasukkan situs ke dalam konteks sistem dan selesai, tetapi juga perlu dibentuk konteks sistem yang tepat. Hal ini perlu dilakukan jika masyarakatnya tidak memiliki hubungan fungsional dengan situs, maka konteks sistemnya harus disertai dengan penciptaan kondisi-kondisi tertentu yang mendukung pemanfaatan dan pelestarian.

Dalam tulisan tersebut Wasita juga menambahkan bahwa untuk urusan pemanfaatan yang berwawasan pelestarian, arkeolog hendaknya tidak mengambil sikap pasif dengan hanya bertindak sebagai fasilitator dan mediator. Sikap ini dianggap pasif karena hanya bersifat melayani. Sebagai pelayan ia tidak akan mengambil tanggung jawab. Posisi tidak mengambil tanggung jawab jika dikaitkan dengan sikap ilmuwan dalam melakukan kerjanya justru akan dianggap bertentangan. Sebab jika dikaitkan dengan hasil kerja arkeolog, wujudnya adalah interpretasi. Interpretasi arkeologi adalah produk sosial masyarakat. Sebagai produsen (interpretasi), sudah selayaknya jika arkeolog tidak lepas tangan atas hasil kerjanya. Justru interpretif yang tidak bisa dilepaskan dari subjektivitas arkeolog itulah yang merupakan tanggung jawab kita.

Ketika dikaitkan dengan posisi sebagai ilmuwan tersebut, tulisan Wasita diakhiri dengan kesimpulan bahwa, arkeolog harus mengambil sikap yang fleksibel. Arkeolog bisa menjadi fasilitator atau mediator jika pemanfaatan masyarakat terhadap situs tidak menyesatkan. Akan tetapi, jika 
Usulan Model Pengelolaan Sumberdaya Budaya:

Pemikiran Berdasarkan Kasus-kasus di Kalimantan 170-194

pemanfaatannya menyesatkan, arkeolog harus mengambil sikap sebagai pengontrol. Sikap sebagai pengontrol dilakukan ketika melihat adanya ketidaktepatan pemanfaatan berdasarkan pengetahuan kita. Sikap sebagai pengontrol inilah yang pada saatnya akan menempatkan arkeolog sebagai ilmuwan yang dibutuhkan. Dalam posisi ini, arkeolog dan arkeologi dapat memperlihatkan kemampuannya tidak hanya sekedar sebagai penyedia salah satu kebutuhan masyarakat, tetapi sebagai penunjuk jalan menuju kehidupan umat yang lebih baik.

Memperhatikan gagasan-gagasan yang tertuang dalam telaah kepustakaan di atas, tampak bahwa ide pemanfaatan dan pelestarian SDB sudah banyak dan bahkan menukik ke arah teknis untuk implementasinya. Berdasarkan hal tersebut, dapat kita lihat bagaimana implementasi pelestarian dan pemanfaatan SDB di Kalimantan.

\section{B. Implementasi Pengelolaan SDB di Kalimantan}

Seperti yang disebutkan di depan, implementasi pelestarian SDB di Kalimantan dipandang masih ada yang belum tepat/ mengena. Bahkan itu terjadi pada banyak situs. Satu dengan yang lain permasalahannya bisa berbeda. Namun demikian, jika dikelompokkan tampaknya ada tiga jenis permasalahan pelestarian. Ketiga jenis permasalahan tersebut adalah standard ganda, persepsi afektif dalam memandang SDB, dan memperjuangkan kepentingan sendiri (kelompok) yang kadang-kadang disertai dengan pengatasnamakan SDB. Namun demikian, disadari juga di antara adanya permasalahan-permasalahan tersebut, juga terdapat pelestarian yang mengena. Hanya saja jika diperhatikan belum semuanya lepas dari masalah.

\section{Standard Ganda}

Adanya standard ganda dapat dilihat dalam pengelolaan bangunan purbakala di Sanga Sanga, utamanya terhadap bangunan kolonial. Dalam hal ini, standard ganda terjadi dalam pelaksanaan pengelolaan. Maksudnya, adanya bangunan cagar budaya yang demikian banyak, dalam pengelolaan/ pelestariannya dilakukan dengan cara dipilih. Jadi ada yang dirawat, tetapi ada juga yang dibiarkan. Standard ganda dalam pelaksanaan pengelolaan yang demikian dilakukan oleh pemerintah dan sebagian pengguna bangunan. Pemerintah dianggap bertindak dengan standard ganda karena sebagian objek tidak atau belum di-BCB-kan dan bangunan yang dihuni masyarakat tidak atau belum disosialisikan statusnya sebagai BCB kepada yang bersangkutan. Buktinya ada sebagian penghuni bangunan kolonial yang tidak tahu bahwa rumah yang ditempatinya adalah cagar budaya. Dalam hal ini, diakui bahwa ada masyarakat yang memperlakukan bangunan purbakala yang ditempatinya dengan baik dan mendukung pelestarian, tetapi sebagian juga ada yang memperlakukan dengan cara kurang mendukung prinsip pelestarian. Dalam hal ini, yang diperlukan adalah menyamakan tujuan akhir , yaitu terlestarikannya bangunan kolonial di Sanga Sanga.

Adanya stakeholder yang tidak mendukung pelestarian dan adanya jumlah bangunan purbakala yang banyak, menyebabkan kekhawatiran karena adanya kemungkinan bangunan-bangunan kolonial di Kecamatan Sanga Sanga terancam 
Usulan Model Pengelolaan Sumberdaya Budaya:

keselamatannya. Jumlah bangunan dan prosentase yang telah terurus dapat dilihat pada uraian di bawah ini. Nugroho Nur Susanto $(2005,13-27)$ menyebut bahwa bangunan kolonial di Sanga Sanga meliputi prasarana kota, sarana pendukung kota, dan tempat aktivitas pertambangan. Prasarana kota meliputi pelabuhan (11 buah), kompleks pemukiman pekerja (10 buah), pengolahan air bersih, pembangkit listrik, rumah sakit, dan pasar. Bangunan sarana pendukung kotanya berupa sarana ibadah (masjid, klenteng, gereja), makam, sekolahan, kantor pos, rumah penjara, tempat olah raga, dan sarana penunjang keamanan, yaitu barak tentara Jepang. Sementara itu, tempat aktivitas pertambangan berupa sumur minyak, perkantoran, pengumpul utama, station pengumpul minyak, pemanas minyak, bengkel perusahaan, dan sarana komunikasi (radio).

Naniek Harkatiningsih melakukan penelitian tentang Pemukiman dan Industri Pertambangan: Pengaruh Kolonial di Kalimantan Timur. Laporan penelitian tersebut ditulis secara tim $(2008,38-55)$ antara lain menyebutkan hasil penelitian di Sanga Sanga. Analisis terhadap situs-situs di Sanga Sanga meliputi 57 nama situs (Tabel 1).

Tabel 1. Situs-situs di Kecamatan Sanga Sanga, Kutai Kertanegara, Kalimantan Timur

\begin{tabular}{|c|c|c|c|c|c|c|c|c|c|}
\hline 1 & Penjara & 9 & $\begin{array}{l}\text { Sumur minyak } \\
935\end{array}$ & 18 & $\begin{array}{l}\text { Gedung } \\
\text { Sandisa }\end{array}$ & 27 & Bangsal 21-24 & 36 & Gudang lodging \\
\hline 2 & Klinik & 10 & Power Plant & 19 & $\begin{array}{l}\text { Instalasi air } \\
\text { minum }\end{array}$ & 28 & Gua (bunker) & 37 & Hiltop housing \\
\hline 3 & Masjid kuna & 11 & Pompa kayu & 20 & Bangsal B30 & 29 & Warehouse & 38 & $\begin{array}{l}\text { Bangsal B10-15, B8-9, } \\
\text { B3-5, Bangsal Tinggi }\end{array}$ \\
\hline 4 & Klenteng & 12 & $\begin{array}{l}\text { Lokasi } 5 \text { sumur } \\
\text { kayu }\end{array}$ & 21 & Perbengkelan & 30 & Gua & 39 & Museum Perjuangan \\
\hline 5 & $\begin{array}{l}\text { Monumen } \\
\text { Merah Putih }\end{array}$ & 13 & Pasar & 22 & $\begin{array}{l}\text { Gedung } \\
\text { Bioskop }\end{array}$ & 31 & $\begin{array}{l}\text { Bekas kolam } \\
\text { renang }\end{array}$ & 40 & $\begin{array}{l}\text { Makam Keramat, } \\
\text { Makam Pahlawan }\end{array}$ \\
\hline 6 & $\begin{array}{l}\text { Bekas markas } \\
\text { KNIL }\end{array}$ & 14 & Tangki besar & 23 & $\begin{array}{l}\text { Wisma Ria dan } \\
\text { kantor pos }\end{array}$ & 32 & Sembat & 41 & $\begin{array}{l}\text { Bekas Rumah Sakit, } \\
\text { Poliklinik MEDCO }\end{array}$ \\
\hline 6 & $\begin{array}{l}\text { Bekas markas } \\
\mathrm{KNIL}\end{array}$ & 15 & $\begin{array}{l}\text { Bekas kantor } \\
\text { BPM }\end{array}$ & 24 & Tangki minyak & 33 & $\begin{array}{l}\text { Sumur Louis I- } \\
\text { II }\end{array}$ & 42 & $\begin{array}{l}\text { Sumur Noni, sumur } \\
\text { gas, sumur } 943\end{array}$ \\
\hline 7 & $\begin{array}{l}\text { Mess } \\
\text { MEDCO }\end{array}$ & 16 & Koramil & 25 & MOS & 34 & Sumur minyak & 43 & Sumur tertua di Noni \\
\hline 8 & $\begin{array}{l}\text { Sumur Minyak } \\
321\end{array}$ & 17 & Bangsal 4 & 26 & $\begin{array}{l}\text { Pemanas } \\
\text { minyak }\end{array}$ & 35 & $\begin{array}{l}\text { Pengumpul } \\
\text { minyak }\end{array}$ & 44 & Kuburan Cina \\
\hline
\end{tabular}


Usulan Model Pengelolaan Sumberdaya Budaya:

Pemikiran Berdasarkan Kasus-kasus di Kalimantan 170-194

Berdasarkan hasil penelitian tahun 2012, masih terdapat situs lain yang belum disebutkan dalam penelitian Nugroho Nur Susanto maupun Tim Peneliti Pusat Penelitian Arkeologi Nasional. Situs-situs tersebut adalah station pengumpul minyak di Distrik V, Gua Jepang di Jalan Habibah Km 3, Kubu Pertahanan Pejuang Merah Putih (menurut informasi ada sembilan lokasi, tetapi dalam penelitian tersebut hanya ditemukan di enam lokasi), dan rumah Belanda yang dibeli dari keturunan Belanda langsung yang ada di Kelurahan Jawa (dahulu ada empat rumah, sekarang yang masih ada tinggal satu rumah).

Dari jumlah situs yang disebutkan di atas, yang telah memiliki juru pelihara adalah Museum Perjuangan dan Sandisa (di bawah Dinas Sosial Kukar), Monumen RIS, Kubu Pertahanan Pejuang Merah Putih, Tugu Pembantaian (Dinas Budparpora). Kemudian ada limpahan karyawan honorer yang digaji oleh Balai Pelestarian Peninggalan Purbakala Samarinda dan Dinas Kebudayaan, Pariwisata, Pemuda, dan Olahraga Kabupaten Kutai Kertanegara berjumlah tiga orang. Pada saat itu, oleh Balai Pelestarian Peninggalan Purbakala Samarinda mereka mendapat tugas menjadi juru pelihara di Momumen Perjuangan, Palagan Merah Putih. Setelah diangkat menjadi Pegawai Negeri Sipil melalui Dinas Kebudayaan, Pariwisata, Pemuda, dan Olahraga Kabupaten Kutai Kertanegara, maka mereka menjadi pegawai dinas tersebut.

Salah seorang staf dinas tersebut menyatakan bahwa mereka bertugas menjaga dan merawat semua situs di Sanga Sanga. Akan tetapi, setelah dikejar dengan pertanyaan berapa situs yang sudah terdaftar sebagai cagar budaya ternyata tidak bisa memberikan keterangan yang pasti. Terlebih lagi ketika ditunjukkan bahwa secara historis ada bangunan yang dahulu berkaitan dengan sejarah kolonial Belanda di Sanga Sanga dan sekarang ini ditempati penduduk, belum terdaftar sebagai cagar budaya. Ternyata yang tinggal di rumah tersebut juga tidak mengetahui jika rumah yang ditempati termasuk cagar budaya. Oleh karena itu, akan menjadi masalah jika para juru pelihara tibatiba datang dan melakukan aksi pemeliharaan rumah tersebut. Kenyataan di lapangan, para juru pelihara dari dinas lebih memfokuskan pemeliharaan di situs-situs yang telah dipasang papan nama sebagai cagar budaya. Hal ini dilakukan sebagai upaya untuk menghindari salah paham dengan orang yang tinggal di rumah atau barak milik Batavia Petroleum Maatschappij (BPM) dulu.

Di sisi lain, ternyata hingga saat ini pihak Balai Pelestarian Peninggalan Purbakala (BP3) Samarinda baru menerbitkan Surat Keterangan Benda Cagar Budaya/Situs di Kecamatan Sanga Sanga sebanyak 19 situs. Menurut buku laporan kegiatan yang dilakukan oleh Dinas Kebudayaan dan Pariwisata Kabupaten Kutai Kertanegara yang bekerja sama dengan BP3 Samarinda disebutkan bahwa pendataan benda/situs purbakala tersebut dilakukan sebagai langkah awal dari kegiatan pelestarian (Tim Penelitian 2010, 1). Hasil tersebut masih merupakan surat keterangan. Jadi hasil pekerjaan tersebut belum merupakan sebuah ketetapan sebagai benda cagar budaya (BCB). Oleh karena itu, wajar jika ada penghuni rumah bekas barak BPM tidak mengetahui jika rumah yang ditempati merupakan BCB. Dalam hal ini, terlihat bahwa laporan kegiatan untuk 
Usulan Model Pengelolaan Sumberdaya Budaya:

menerbitkan surat keterangan $\mathrm{BCB}$ tersebut dilakukan dengan cara memilih, dan hanya sebagian kecil yang terpilih.

Padahal, bekas kantor BPM di Sanga Sanga dan bangunan-banguan lainnya merupakan tinggalan purbakala. Keyakinan ini diperoleh dari buku laporan inventarisasi yang menunjuk beberapa bangunan tinggalan dari BPM dulu. Jika kemudian inventarisasi yang dilakukan tidak menyentuh semua bangunan eks BPM, maka pemilihan yang dilakukan kelihatan tidak adil. Ini membuktikan bahwa langkah pelestarian dari pemangku kepentingan pihak kepurbakalaan sendiri dilakukan dengan cara memilih, tampaknya ada standard ganda dalam hal ini.

Hal ini baru dilihat dari sisi stakeholder pemerintah. Padahal pemangku kepentingan juga berasal dari masyarakat dan instansi pengguna bangunan tersebut. Bangunan bekas gedung dan barak BPM sekarang ini dikuasai oleh pihak Pertamina EP sebagai pihak pemegang konsesi negara. Pihak humas pertamina mengatakan bahwa pertamina hanya menyewa dan sementara pemiliknya adalah negara. Sebagai pemegang konsesi, Pertamina bertanggung jawab atas keutuhan aset yang mereka sewa. Aset yang disewa Pertamina adalah lahan tambang minyak di Sanga Sanga dan bangunan yang berdiri di atasnya yang dahulu merupakan bangunan yang didirikan oleh perusahaan BPM. Dalam hal ini Pertamina tahu bahwa aset yang berupa bangunan merupakan tinggalan purbakala.

Anggapan bahwa mereka tahu asetnya merupakan bangunan purbakala diindikasikan dari pemahaman mereka (staf humas) di mana pihak Pertamina di Sanga Sanga tidak boleh melakukan rehab dan renovasi gedung lama tanpa persetujuan dari
Pertamina Pusat. Sementara itu, untuk urusan renovasi kecil-kecilan Pertamina Sanga Sanga boleh melakukannya tanpa meminta persetujuan pusat. Namun demikian, mereka (Sanga Sanga) telah dipesan agar renovasi kecil yang kemungkinan dilakukan, tidak akan mengubah bentuk. Hal yang demikian ini telah dipahami oleh staf Pertamina di Sanga Sanga baik di unit kantor pusatnya, Elektra (wawancara salah seorang pekerja bengkel) dan di kliniknya (wawancara dengan perawat).

Lantas bangunan purbakala yang berasal dari masa pengeboran minyak Belanda dan Jepang dulu, kini keberadaannya ada yang dimanfaatkan oleh Pertamina, tetapi ada juga yang dimanfaatkan oleh masyarakat dan instansi lain, misalnya kepolisian, Komando Rayon Militer (Koramil), dan yayasan sekolahan YPTH di Sanga Sanga. Dalam menanggapi adanya dua pihak yang berstatus sebagai pemakai, yaitu mereka sendiri (Pertamina) dan pihak lain di luar mereka (kepolisian, Koramil, yayasan, dan masyarakat umum), Pertamina menggunakan standart ganda. Terkait dengan diri mereka sendiri, intruksi bahwa renovasi tidak boleh merubah bentuk, diimplementasikan dalam merenovasi bangunan-bangunan dengan tetap mempertahankan bentuk walaupun bahannya beda. Hal ini dilakukan untuk bangunan-bangunan yang digunakan oleh Pertamina.

Sementara itu, aset mereka yang sejauh ini dipinjamkan kepada anggota Kepolisian Sektor (Polsek) Sanga Sanga, Koramil, yayasan, dan perorangan, strategi Pertamina lebih ditekankan pada substansi agar tanah tempat berdirinya bangunan tidak hilang. Maksudnya, Pertamina lebih menitikberatkan pada upaya kepemilikan tanahnya. Strategi ini dilakukan karena dalam pandangan mereka 
Usulan Model Pengelolaan Sumberdaya Budaya:

Pemikiran Berdasarkan Kasus-kasus di Kalimantan 170-194

bangunan tersebut sudah tidak bisa dimanfaatkan. Mereka beranggapan jika bangunan seperti barak hutan misalnya, digunakan bagi karyawan Pertamina dinilai tidak layak dan tidak manusiawi. Tidak sepantasnya karyawan Pertamina menempati rumah yang demikian (Foto 1). Namun di sisi lain, mereka tidak ingin kehilangan tanah yang digunakan sebagai tempat berdirinya bangunan. Upaya tersebut kemudian dilakukan dengan meminjamkan bangunan tersebut kepada pihak lain. Menurut Pertamina, barak yang tidak ditempati rawan hilang mulai dari kayu-kayunya hingga tanahnya.

Sementara itu, kepada para peminjam, pihak Pertamina memesankan cara yang sama yang ia terima dari pimpinan mereka di Pusat, agar tidak merubah bentuk bangunan. Selain memberikan pesan tersebut, pihak Pertamina juga secara rutin melakukan kontrol kepada para peminjam. Kontrol tersebut dilakukan dengan cara mengecek keberadaan rumah dan memberikan tempelan stiker yang menunjukkan bahwa bangunan tersebut merupakan rumah dinas karyawan Pertamina yang dimiliki negara (Foto 2). Tampaknya apa yang dilakukan Pertamina dimaksudkan sebagai upaya mengontrol keberadaan rumah yang ia pinjamkan. Jadi, mengontrol rutin dan menempel stiker adalah salah satu cara untuk menunjukkan kepada pihak lain bahwa negara dan melalui merekalah (Pertamina), aset tersebut harus dikuasai.

Namun demikian, pihak Pertamina juga hanya sekedar memastikan bahwa merekalah yang berhak menguasai bangunan dan tanahnya. Buktinya, Pertamina tidak peduli apa yang sebenarnya terjadi pada bangunan tersebut dan bagaimana pihak peminjam memperlakukannya. Hal itu dapat ditunjukkan dari tidak ada upaya membantu pemakai dalam perawatan bangunan dan pemberian fasilitasnya. Tindakan tidak membantu perawatan terlihat dari adanya kondisi bangunan yang rusak dan sudah seharusnya direnovasi tetapi Pertamina tidak melakukan apa-apa. Oleh karena itu, banyak pemakai yang kemudian melakukan inisiatif merenovasi bangunan yang ia tempati. Alhasil, ada beberapa bangunan yang sudah mengalami perubahan (Foto 3 dan 4). Di samping itu, berkaitan dengan fasilitas rumah juga kurang diperhatikan, bahkan mengenai hal yang terkait dengan status kepemilikan pun kurang diperhatikan. Contohnya, rumah memerlukan listrik untuk penerangan, tetapi pihak pertamina sebagai pemilik konsesi dan pemilik konsesi sebelumnya (Medco, misalnya) tidak mengusahakan hal tersebut. Akibatnya, semua pengguna bangunan tersebut listriknya sudah tidak dari PTL (Pembangkit Tenaga Listrik) lagi. Padahal dahulu semua gedung dan barak karyawan difasilitasi listrik dari PTL. Oleh karena sekarang tidak lagi difasilitasi, maka mereka menyambung listrik dari PLN (perusahaan listrik Negara).

Ironisnya, jika hak milik dan penguasaan selalu ditegaskan adalah oleh Pertamina, untuk urusan yang mengeluarkan biaya dan berkaitan dengan wajarnya sebuah kepemilikan, hal itu masih dibebankan kepada para peminjam. Dalam hal ini rekening listrik. Dalam upaya mengurus adanya penerangan di rumah tinggalnya, para peminjam barak mengurus listrik ke PLN dan untuk administrasi digunakan namanya sendiri, bukan nama pemilik yang sebenarnya (negara, melalui Pertamina). Di sini 
Usulan Model Pengelolaan Sumberdaya Budaya:

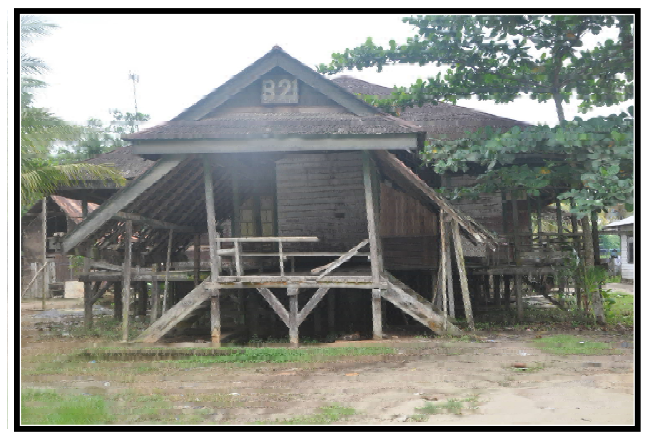

Foto 1. Bangsal Jepang, salah satu tinggalan kolonial di Sanga Sanga yang saat ini dihuni oleh orang angkatan darat yang bekerja di Koramil

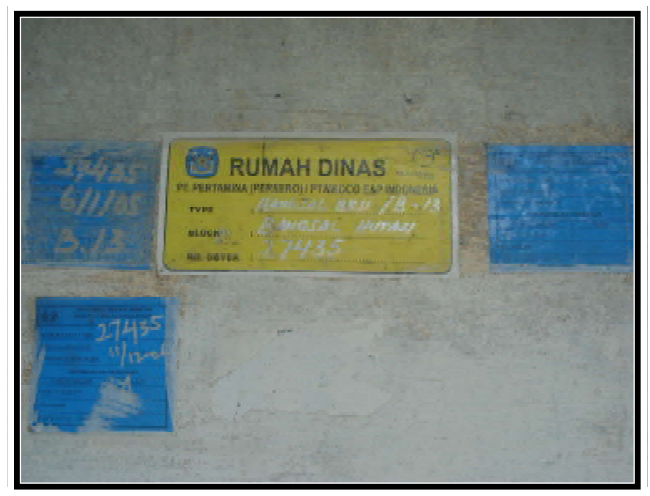

Foto 2. Stiker yang ditempel oleh Pertamina
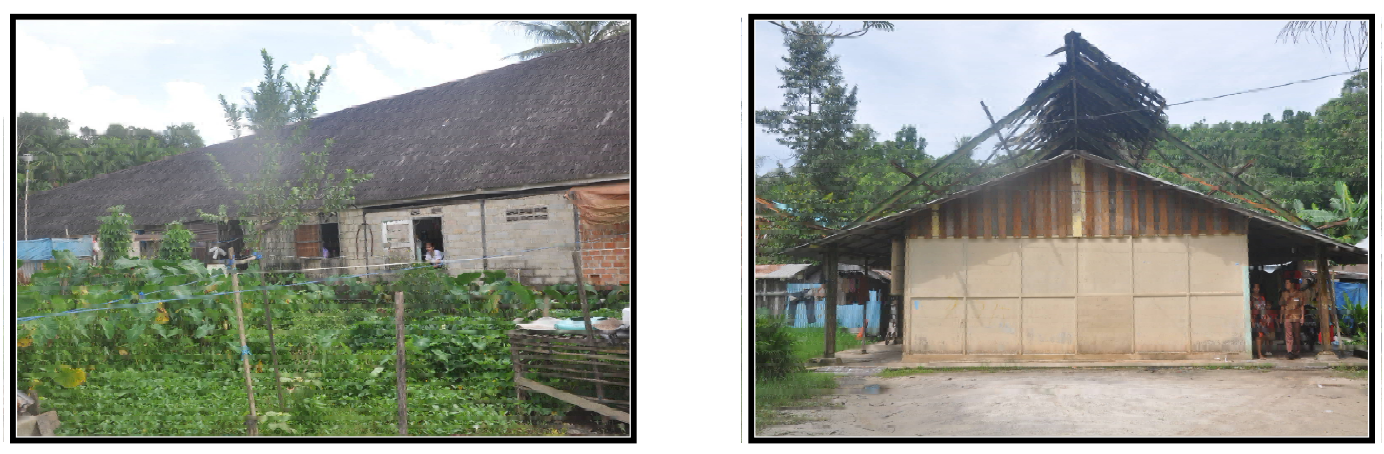

Foto 3 dan 4. Perubahan barak hasil renovasi penghuni

Pertamina menggunakan standard ganda dalam menangani aset mereka. Pertamina hanya mau melakukan perawatan terhadap bangunan yang ditempati, sementara yang dihuni peminjam tidak dibantu. Kedua, terhadap rumah yang dipinjamkan. Secara aset, pertamina selalu memutakhirkan kepemilikan, tetapi tiba gilirannya mengeluarkan biaya untuk lebih menegaskan akan haknya (biaya pemasangan saluran listrik) hal itu tidak mereka lakukan. Bahkan dari yang sudah ada listrik PTL di putus. Tampaknya, standard ganda tersebut dilakukan sebagai upaya untuk mengurangi biaya, namun tetap ingin mempertahankan hak miliknya. Akibatnya, terkait dengan tanggung jawab dalam beberapa hal dilimpahkan kepada pihak lain (peminjam). Dengan demikian, penggunaan standard ganda berdampak pada kegiatan pelestarian, karena ada cagar budaya yang terpilih untuk dikelola dan ada yang tidak. 
Usulan Model Pengelolaan Sumberdaya Budaya:

Pemikiran Berdasarkan Kasus-kasus di Kalimantan 170-194

\section{Perpsektif Subjektif dan Afektif}

Dalam Kamus Besar Bahasa Indonesia, subjektif dimaknai menurut pandangan (perasaan) sendiri. Dalam Ensiklopedi Umum, afektif didefinisikan sebagai suasana perasaan yang menyertai suatu ide, pikiran atau peristiwa mental. Berkaitan dengan hal tersebut John S. Nimpoeno (1980, 29-30) menyatakan bahwa:

"....jika warisan budaya dipersepsikan dengan cara afektif, maka warisan budaya tersebut akan mendapat makna yang bias dari yang semestinya dan bahkan makna tersebut serasa dibesar-besarkan."

Dengan demikian, warisan budaya pada umumnya dapat dipersepsikan dengan cara yang berbeda antara orang yang satu dengan lainnya.

Namun yang terjadi pada sebagian SDB di Kalimantan hal tersebut dibenarkan oleh pengelola itu sendiri. Maksudnya, pengelola cenderung tidak peduli dengan pemahaman pengunjung yang melakukan ziarah, misal di Candi Agung, makam Sultan Suriansyah, dan Datu Sanggul. Memang benar, sebagian pengunjung menganggap bahwa Candi Agung sebagai tempat ziarah. Wasita (2011b, 75 ; 121) menyebutkan bahwa pengunjung yang melakukan ziarah mendatangi candi untuk berdoa, memohon kepada "orang halus" yang menjaga candi. Maksud permohonannya antara lain untuk mendapatkan berkah (sembuh dari sakit, mendapatkan kemudahan hidup, dan lain sebagainya), menuntaskan nazar (telah mendapatkan sesuatu yang diinginkan, telah sembuh dari sakit, dan lain sebagainya), dan bailang (datang untuk bertemu "orang halus", dalam hal ini berarti terus-menerus berusaha menjalin hubungan dengannya).
Adanya sinyalemen bahwa para pengelola membenarkan ditunjukkan oleh pemberian fasilitas untuk keperluan tersebut dengan cara membiayai pembangunan gedung dan kamar mandi untuk kenyamanan peziarah. Oleh karena dalam berdoa mereka memerlukan tempat, maka dibangunkan pendopo untuk kegiatan melakukan doa. Sebagian dari mereka, ziarahnya dengan laku mandi di Tiang Sembilan, maka pengelola membangun ruangan ganti baju dan kamar mandi.

Di makam Datu Sanggul dan Sultan Suriansyah juga ada fasilitas ruang di cungkup makam. Ruang tersebut dimaksudkan sebagai lokasi mangkalnya para pemandu ritual dalam menunggu peziarah yang datang meminta bantuan memimpin doa dalam ziarahnya dan kadang ada juga yang datang meminta air untuk pengobatan. Perilaku pengelola yang demikian ini sama dengan mengamini persepsi peziarah. Padahal dari segi historis dan religi antara orang yang melakukan ziarah dan objek yang diziarahi tidak ada kaitan sama sekali. Mereka yang melakukan ziarah adalah orang Islam dan yang diziarahi adalah candi. Sementara itu, yang dianggap sebagai penunggunya adalah Suryanata yang dalam riwayatnya merupakan raja Kerajaan Negaradipa dan berkeyakinan Hindhu.

Ironisnya, apa yang dilakukan pengelola Candi Agung sebenarnya tidak mutlak mengakibatkan peziarah akan selalu datang ke tempat tersebut. Ada faktor lain yang menjadikan peziarah mengunjungi candi, yaitu sikapnya yang percaya bahwa "orang halus" masih tinggal di sana. Dalam hal ini peziarah memiliki mindset bahwa orang halus tinggalnya selalu di tempat yang ia senangi. 
Usulan Model Pengelolaan Sumberdaya Budaya:

Menurut peziarah, tempat-tempat yang disenangi orang halus adalah yang tidak terlalu bising dan tidak terlalu terang. Dengan demikian dalam persepsi peziarah, membangun fasilitas ziarah bukan satusatunya cara untuk mempertahankan agar pengunjung/peziarah tetap banyak. Sebab jika peziarah kemudian meyakini bahwa "orang halus" sudah tidak senang lagi tinggal di Candi Agung, maka mereka tidak lagi ke candi. Sebab yang mereka datangi sebenarnya adalah "orang halus". Jadi masalah agar pengunjung selalu datang ke candi terletak pada mind set pengunjung.

Hal yang mirip juga terjadi di situs makam Sultan Suriansyah (Banjarmasin) dan Datu Sanggul (Kabupaten Tapin), Kalimantan Selatan. Para pengunjung di kedua makam tersebut rata-rata juga untuk melakukan ziarah. Ada model berpikir yang umum di kalangan peziarah, bahwa sebagian tokohtokoh besar, utamanya dari kraton, tidak mengalami kematian, tetapi yang terjadi adalah wapat. Menurut Alfani Daud (1997, 406) wapat dialami oleh orang yang kembali ke asal atau menjadi gaib. Oleh karena menjadi gaib maka ia tetap hidup tetapi menjalani kehidupannya di alam sebelah (alam gaib).

Selain peziarah Candi Agung, yang mempercayai hal demikian ini juga para peziarah di kedua makam tersebut. Disinyalir, mempercayai yang demikian ini dapat menimbulkan kerugian di kedua belah pihak, yaitu pengelola kepurbakalaan dan pengunjung yang bersangkutan. Kerugian bagi pengelola terletak pada upaya untuk memberikan pemahaman sejarah dan kebudayaan tentang objek yang ditampilkan tidak mengena sehingga gagal dalam mentransfer pengetahuannya kepada para pengunjung/peziarah. Kedua, peziarah itu sendiri tidak berhasil mendapatkan pencerahan yang sebenarnya. Sebaliknya, ia hanya mendapatkan pencerahan semu, yang kadang-kadang secara logika tidak bisa diyakini kebenarannya.

Melihat kenyataan yang demikian ini, perlu adanya upaya-upaya dari pihak pengelola agar SDB yang ada di lingkungannya dapat memberikan manfaat yang sebesar-besarnya, baik dari segi material maupun imaterial. Upaya tersebut antara lain dapat dilakukan dengan penyebaran informasi yang benar kepada masyarakat luas. Setelah program penyebaran informasi seharusnya juga ada tindak lanjut untuk mengetahui hasil penyebaran tersebut. Sebab, sangat mungkin yang telah dilakukan ternyata tidak mengenai sasaran atau tepat sasaran, tetapi tidak memberi dampak apapun.

Berkaitan dengan hal tersebut Wasita (2010) pernah mencoba melihat hal tersebut terhadap pengelola dan masyarakat pengunjung Candi Agung. Dalam pandangannya, penyebaran informasi kepurbakalaan terhadap instansi yang terkait dengan Candi Agung tidak membawa dampak dalam cara mengelola BCB. Ternyata setelah dikonfirmasi kepada pengelolanya, justru yang bersangkutan tidak mengetahui kalau ada tulisan-tulisan terkait Candi Agung yang dimiliki oleh kantor induknya. Ironisnya, sejauh ini yang menjadi pemikiran adalah meraih target yang dibebankan oleh atasannya, yaitu jumlah pemasukan melalui penjualan tiket masuk candi. 
Usulan Model Pengelolaan Sumberdaya Budaya:

Pemikiran Berdasarkan Kasus-kasus di Kalimantan 170-194

\section{Memperjuangkan Kepentingan Sendiri \\ Seperti ungkapan umum yang abadi} dalam kehidupan manusia adalah kepentingan. Hal ini pula yang antara lain mewarnai pengelolaan SDB di Kalimantan. Kepentingan yang diperjuangkan oleh yang bersangkutan adalah untuk mendapatkan keuntungan. Dalam hal ini kepentingan seseorang akan sangat dipengaruhi oleh kebutuhan atau tujuan hidup, aturan-aturan yang mengikatnya, dan pengetahuanpengetahuan yang membentuk persepsi seseorang. Ketiga hal tersebut jalin-menjalin membentuk perilaku manusia dalam memperjuangkan kepentingannya. Dalam relasi ini pula situs/bangunan purbakala hadir dalam sistem kehidupan manusia dan mendapat perlakuan.

Kepentingan tersebut tidak mutlak berasal dari masyarakat. Pihak pengelola pun atau stakeholder dari pemerintah, ada yang berada dalam kategori ini. Masyarakat mapun pengelola bisa berada dalam kategori ini karena mereka kurang memahami makna dan esensi tinggalan purbakala. Akibatnya persepsi mereka tidak mengarahkan pada perilaku dan penempatan SDB dalam konteks sistem yang tidak mendukung pelestarian.

Berkaitan dengan masalah yang demikian ini, Pemerintah Kabupaten Ketapang (Kalimantan Barat) dan Kutai Kertanegara (Kalimantan Timur) melalui dinas yang mengurusi kebudayaan masingmasing mencoba menindaklanjuti rekomendasi penelitian arkeologi yang dilakukan Balai Arkeologi Banjarmasin bahwa perlu pembebasan tanah di lokasi temuan Candi di Negeri Baru, Ketapang dan Kubur Tajau Sanga Sanga, Kutai Kertanegara agar data-data terselamatkan dan penelitian dapat dilakukan dengan lebih leluasa. Alhasil, kedua upaya tersebut gagal. Pembebasan tanah untuk Candi di Negeri Baru gagal di tingkat pembahasan DPRD. DPRD Ketapang sebenarnya menyetujui pembebasan tanah yang diajukan Dinas Budparpora, tetapi lokasi dan peruntukannya berbeda. Oleh karena dinas tersebut juga mengurusi olah raga, pembebasan tanah tersebut dialihkan tempat dan peruntukkannya, yaitu untuk lapangan olah raga. Kabar dari Kutai Kertanegara justru lebih kacau lagi. Tidak diketahui alasannya, yang jelas dicoret dan tidak disetujui.

Hal yang demikian ini menunjukkan bahwa sebagian tokoh di tingkat DPRD belum dapat melihat nilai penting tinggalan purbakala. Menjadi tidak aneh jika ada usulanusulan yang terkait dengan kepurbakalaan dapat dikalahkan dan dialihkan untuk hal yang lain. Atau bisa jadi justru pihak dinas yang kurang mampu meyakinkan bahwa usulannya sangat logis dan bermanfaat untuk bangsa.

Fenomena yang demikian ini (kebijakan SDB di tingkat daerah) bisa berbeda jika berada di tangan seorang bupati. Hasil penelitian Balai Arkeologi Banjarmasin tentang Benteng Pengaron tahun 2005 tidak ada gemanya sama sekali di tingkat birokrat Kabupaten Banjar. Tetapi setelah tahun 2012 ini ramai dibicarakan di media massa setempat tentang sisa pertambangan batubara pada masa kolonial Belanda, maka tanggapan muncul dari berbagai elemen masyarakat. Dari sini Bupati Banjar mulai menaruh perhatian. Sebagai upaya untuk memperjelas keberadaan tinggalan pertambangan masa Belanda di wilayah Kabupaten Banjar, akhirnya dilakukan kerjasama dengan Balai Arkeologi 
Usulan Model Pengelolaan Sumberdaya Budaya:

Banjarmasin untuk melakukan penelitian. Kerjasama juga dilakukan untuk studi kelayakan atas tinggalan rumah Banjar di Kecamatan Karangintan, Martapura Barat, dan Martapura Kota yang menjadi identitas urang banua untuk dipastikan layak tidaknya menjadi cagar budaya.

Dalam hal ini terlihat bahwa di tangan siapa rencana itu berada, akan menentukan jalan atau tidaknya program. Jika rencana ada di tangan orang atau pejabat kecil maka ada kemungkinan tidak terlaksana. Akan tetapi, jika berada di pucuk pimpinan, sangat besar kemungkinan program tersebut berlangsung.

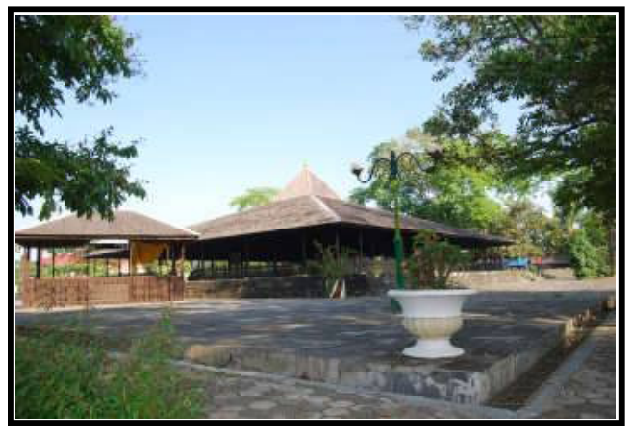

Foto 5. Hasil pemugaran Candi Agung yang dimaksudkan untuk memperindah dilakukan dengan memasang paving blok di sekeliling candi

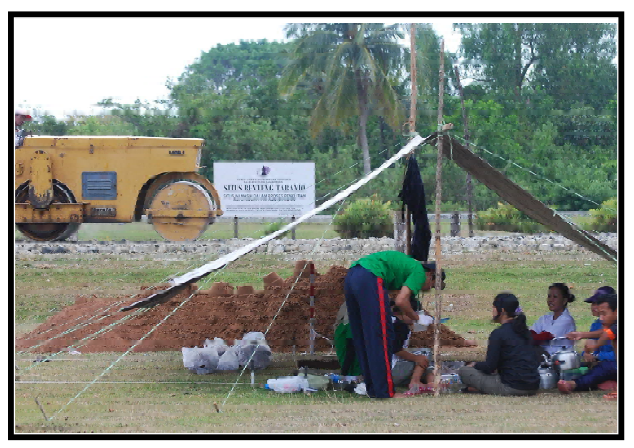

Foto 6. Benteng Tabanio diterjang pembangunan jalan
Candi Agung pun pernah mengalami hal yang kurang lebih demikian. Bupati saat itu menginginkan Kabupaten Hulus Sungai Utara memiliki sumber devisa antara lain dari sektor pariwisata kunjungan candi. Agar merangsang pengunjung lebih banyak lagi, digagas oleh bupati agar Candi Agung dipugar hingga bentuknya mirip dengan candi-candi di Jawa. Bahkan berita di media massa yang bisa diunduh di internet (http://www2.kompas.com/ gayahidup/news/0407/27/120515.htm) menyebutkan bahwa guna mewujudkannya, direncanakan bekerjasama dengan "orang pintar" untuk mengetahui bentuk asli candi dan nantinya akan diwujudkan dalam pemugaran.

Rencana ini mendapat apresiasi dari Balai Arkeologi Banjarmasin dengan menyelenggarakan seminar sehari yang dilaksanakan di Pendopo Kabupaten Hulu Sungai Utara, dengan Bupati sebagai

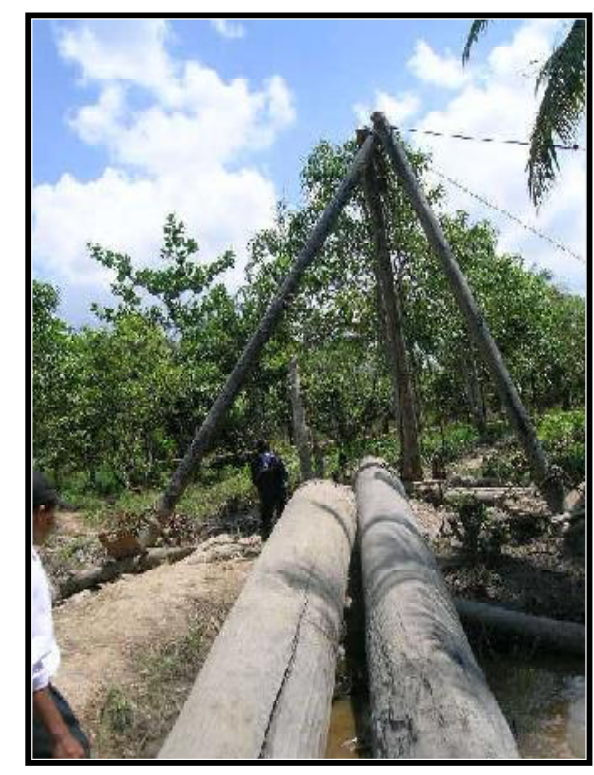

Foto 7. Temuan kayu di Patih Muhur diangkat dengan krain 
Usulan Model Pengelolaan Sumberdaya Budaya:

Pemikiran Berdasarkan Kasus-kasus di Kalimantan 170-194

pembuka acara dan mengundang DPRD setempat, dinas-dinas terkait, cendekiawan, dan tokoh-tokoh masyarakat. Hasil diskusi jelas bahwa pemugaran dengan target yang direncanakan tersebut tidak mungkin dilakukan (Gunadi 2005), pembangunan fasilitas baru di kawasan candi hanya mungkin dilakukan di zona penyangga (Ismiyono 2005). Namun demikian, hasil seminar tersebut tidak mutlak mempengaruhi rencana yang tampaknya tinggal dijalankan karena anggarannya telah tersedia. Buktinya, memugar candi agar seperti candi-candi di Jawa tidak jadi dilakukan, tetapi rencana membangun fasilitas baru yang dimaksudkan untuk "memperindah" candi, tetap jalan. Memang ada pengurangan-pengurangan, tetapi masih ada yang menyalahi prinsipprinsip pemugaran (Foto 5 ).

Demikian ini gagasan dan rencana yang menyangkut pucuk pimpinan. Rencana dari pucuk pimpinan Dinas Pekerjaan Umun Kabupaten Tanah Laut, Kalimantan Selatan pun tetap jalan jika yang kena dampaknya adalah pemangku kepentingan dari Dinas Kebudayaan dan Pariwisata yang eselon atau kedudukannya setara dengannya, serta BP3 Samarinda dan Balai Arkeologi Banjarmasin yang merupakan UPT yang berbeda garis koordinasinya. Hasilnya, rencana pembangunan jalan yang melintas di atas bekas bangunan Benteng Tabanio pun tetap jalan (Foto 6).

Sementara itu kasus-kasus yang menyangkut orang kecil dan rakyat biasa, ceritanya akan lain. Tahun 2007, seorang pengusaha penggergajian kayu di Banjarmasin, melihat adanya tonggaktonggak kayu di Patihmuhur, Kabupaten Barito Kuala dan kemudian membeli tanah tempat tonggak-tonggak kayu tersebut berdiri. Sebagai pengusaha, ia kemudian ingin memanfaatkan kayu tersebut dengan cara menjadikannya sebagai bahan bangunan ataupun bahan meubel. Oleh karena ukuran kayu yang besar dan jumlahnya banyak, maka pengangkatan yang dilakukan menjadi perhatian banyak warga (Foto 7). Berita dari mulut ke mulut pun tersebar luas. Wartawan juga berdatangan. Akhirnya hal tersebut menjadi pemberitaan media lokal dan nasional, misal Kompas dan Metro TV.

\section{Usul Model Pengelolaan}

Memperhatikan permasalahanpermasalahan yang muncul dalam pengelolaan SDB seperti yang disebutkan di atas, tampaknya perlu dilakukan dua hal, yaitu langkah pengelolaan dengan jalur konvensional dan media massa. Dalam model yang disebutkan tadi sebenarnya dua jalur di atas hanya merupakan pintu masuk. Sebagai sebuah pintu masuk keduanya hanya berfungsi mengantarkan pada langkah aksi pengelolaan. Maksudnya, melalui pintu mana akan masuk menuju pengelolaan SDB merupakan pilihan pertama yang perlu kita tentukan agar diperoleh hasil yang maksimal.

Dalam hal ini yang lebih penting adalah pengaruhnya setelah menemukan pintu masuk yang tepat. Jika tidak memperhatikan situasi dan akhirnya memilih pintu masuk yang salah, dampaknya langkah ke depan dalam implementasi pengelolaan bisa menemui kendala. Ini semua bisa terjadi karena menyangkut kekuasaan atau persepsi seseorang yang didukung oleh tujuan-tujuan hidupnya (upaya memperjuangkan kepentingannya). 
Usulan Model Pengelolaan Sumberdaya Budaya:

Jika menemui kendala dengan pemegang kekuasaan (legislatif dan yudikatif), maka rencana-rencana terkait dengan pengelolaan bisa mental (tidak berjalan dengan mulus). Hal ini sudah bisa kita lihat contohnya dalam kasus Situs Negeri Baru, Ketapang, Kalimantan Barat dan Situs Kubur Tajau Sanga Sanga, Kutai Kertanegara, Kalimantan Timur. Permasalahan karena menemui persepsi seseorang yang menjadikan langkah pelaksanaan pengelolaan berbenturan kepentingannya dengan stakeholder bisa berakibat pengelolaan tidak terlaksana.

Sebagai pintu masuk, keduanya hanya merupakan pilihan. Kita bisa memilih yang mana dan itu ditentukan oleh kondisi yang melatarbelakangi obyek kepurbakalaan yang kita kelola dalam pelestarian. Jika kondisi normal dan tidak ada masalah, jalur konvensional bisa dipilih. Jalur konvensional juga masih dapat dipilih jika terhadap obyek ada masalah, tetapi relatif mudah diselesaikan. Ketika masalah yang menimpa terasa berat dan tidak mampu ditembus dengan jalur konvensional, saat itu dapat ditempuh jalur media massa.

Langkah yang ditempuh dalam jalur ini adalah melontarkan isu mengenai permasalahan pengelolaan kepurbakalaan di media massa. Hal ini dapat dilakukan dengan cara mengundang wartawan atau arkeolog sendiri yang harus menulis permasalahan tersebut di media massa. Tentu saja masalah dilontarkan berkaitan dengan upaya pelestarian yang menemui kendala dan akibat-akibat yang mungkin terjadi atas keadaan yang demikian. Diharapkan dengan lontaran isu tersebut akan mendapat tanggapan baik dari cendekiawan, budayawan, aparat hukum, pemegang kekuasaan, masyarakat luas, dan juga elemen lain yang peduli dengan kepurbakalaan.

Harapannya melalui ini akan diperoleh dukungan kepada pihak kepurbakalaan. Pada titik ini akan segera masuk ke implementasi pengelolaan, yang dalam situasi yang normal langkah pengelolaan akan langsung mulai dari sini. Jika melibatkan media massa, diupayakan untuk terus dipertahankan. Maksudnya, langkah-langkah berikutnya yang ditempuh dan dilakukan dalam kaitannya dengan pengelolaan kepurbakalaan perlu disebarluaskan ke media massa.

Ada dua hal yang diperoleh dari upaya mempertahankan media massa di sini. Pertama, kita berkesempatan menunjukkan kepada masyarakat luas niat baik atau upaya serius yang dilakukan dalam pengelolaan kepurbakalaan. Dalam kesempatan ini kita juga dapat mengupayakan untuk memperoleh simpati dari masyarakat luas. Simpati dapat kita rebut dengan cara memberdayakan masyarakat (Sulistyanto), menempatkan diri sebagai fasilitator dan mediator (Tanudirjo $2000,19)$, dan juga sebagai pengontrol (Wasita 2011a, 15). Kedua, langkah-langkah selanjutnya dalam pengelolaaan masih akan terus dikontrol baik oleh media, masyarakat umum dan juga berbagai elemen masyarakat yang peduli dengan kepurbakalaan. Situasi tersebut akan menjadi sistem pengawasan umum yang dapat mendorong untuk terus dalam melanjutkan program pelestarian.

Jika pintu masuk yang kita pilih tepat, semua akan tampak menjadi mudah untuk dilaksanakan. Contohnya, ketika pemerintah Daerah Kabupaten Banjar, Kalimantan Selatan mulai menunjukkan niatnya untuk melakukan pengelolaan warisan purbakala setelah media massa setempat mewartakan keadaan Bekas Pertambangan Belanda di 
Usulan Model Pengelolaan Sumberdaya Budaya:

Pemikiran Berdasarkan Kasus-kasus di Kalimantan 170-194

Pengaron, Kabupaten Banjar, maka setelah itu banyak ide bermunculan untuk menggarap situs dan banguan purbakala. Bermula dari rencana penyelamatan bangunan bekas pertambangan, kini melalui Anggaran Biaya Tambahan (ABT) tahun 2012 Pemerintah daerah Kabupaten Banjar (langsung di bawah pengawasan Bupati) bekerja sama dengan Balai Arkeologi Banjarmasin akan mengadakan penelitian Benteng Pengaron dan lokasi pertambangannya.

Dalam hal ini pihak pemerintah daerah menargetkan bahwa hasil penelitian tersebut nantinya akan dapat dijadikan sebagai bukti, karena juga akan didirikan monumen perjuangan urang banua (masyarakat Kalimantan Selatan) dalam mengusir penjajah dari tanah kelahiran mereka. Tampaknya tinggalan sejarah dan monumen yang akan mereka dirikan nantinya akan dijadikan sebagai kebanggaan sejarah peran mereka dalam mendirikan Negara Kesatuan Republik Indonesia. Ini semua terjadi karena pintu masuknya tepat, sehingga sekali masuk rentetannya panjang.

Buktinya masih di tahun yang sama, 2012 ini nanti, Dinas Kebudayaan dan Pariwisata Kabupaten Banjar juga meminta Balai Arkeologi Banjarmasin untuk melakukan studi kelayakan atas rumah Banjar (rumah bubungan tinggi, yaitu rumah khas masyarakat Kalimantan Selatan) beberapa makam Islam. Hasil studi kelayakan ini nantinya akan dijadikan sebagai dasar dalam mengurus penetapan obyek tersebut sebagai BCB. Tampaknya pihak dinas akan memasukkan obyek-obyek tersebut menjadi bagian dari paket wisata budaya yang selama ini telah ada, namun bangunan khas masyarakat Banjar dan wisata ziarah tersebut belum menjadi bagiannya.
Hal ini terjadi karena pintu masuk yang sudah terbuka dan kemudian ditindaklanjuti. Setelah terbukanya pintu masuk diyakini akan ada kemudahan-kemudahan dan dukungan dari pemerintah setempat untuk urusan pelestarian kepurbakalaaan. Oleh karena itu, perlu segera dimanfaatkan semua peluang untuk mengelola kepurbakalaan demi pemanfaatan yang baik dan berguna untuk bangsa dan negara serta, kehidupan yang lebih baik.

Dalam implementasi pengelolaan, yang dilakukan adalah mengelola persepsi dan kepentingan, penerapan aturan yang berkaitan dengan rambu-rambu pengelolaan, dan penciptaan konteks sistem yang mendukung pelestarian. Persepsi merupakan landasan stakeholder/pemangku kepentingan situs, terutama dari masyarakat dalam keikutsertannya menjalankan pengelolaan. Penerapan aturan dalam pengelolaan merupakan dasar bagi pemangku kepentingan dari pihak pemerintah dalam mengelola kepurbakalaan. Konteks sistem sebenarnya merupakan situsasi yang terjadi dengan sendirinya karena sistem yang dikembangkan masyarakat memang melibatkan situs/bangunan purbakala yang ada di lingkungan mereka.

Persepsi yang selaras dengan aturan pengelolaan merupakan modal yang sangat baik dari masyarakat terkait dengan keterlibatannya dalam pengelolaan kepurbakalaan. Sementara itu, persepsi yang tidak mendukung upaya pelestarian adalah hal yang harus dikelola lebih jauh agar berubah dan menjadi selaras dengan peraturan dan bersifat melestarikan. Kenyataan di lapangan, aturan yang menjadi acuan aparat pemerintah dalam mengelola SDB belum tentu jika diterapkan tanpa 
Usulan Model Pengelolaan Sumberdaya Budaya:

masalah. Dalam hal ini biasanya masalah akan muncul jika aturan tidak diterapkan dengan ketat.

Berkaitan dengan konteks sistem, sebenarnya bisa terjadi karena bentukan atau asli. Baik bentukan maupun asli, keduanya bisa ada yang bersifat mendukung dan yang tidak mendukung pelestarian. Dalam hal ini yang perlu dilakukan adalah mengarahkan konteks sistem yang belum/tidak mendukung pelestarian agar menjadi/menuju pada konteks sistem yang mendukung pelestarian. Sementara itu, yang belum berada dalam konteks sistem perlu dibentuk konteks sistem yang mendukung pelestarian. Dengan demikian membentuk konteks sistem merupakan salah satu pengelolaan SDB.

Contohnya, persepsi Pertamina Sanga Sanga yang mendapat instruksi dari pusat (Jakarta) agar perlakuan terhadap bangunan yang mereka sewa (Pertamina sebagai pemegang konsesi dari negara), yaitu bangunan tinggalan BPM, tidak dilakukan perubahan bentuk jika terpaksa melakukan renovasi. Instruksi ini kemudian dikaitkan dengan tujuan bisnis Pertamina cabang Sanga Sanga dengan mempersepsikannya sebagai upaya mempertahankan aset (tanah dan bangunan) dan melepas tanggung jawab pelestarian dengan membebankan kepada pemakai (masyarkat dan instansi yang dipinjami). Ini semua terjadi karena instruksi yang ada memang hanya sebatas itu. Sampai di sini kita dapat memastikan bahwa sejauh ini persepsi mereka bukan atau tidak terkait dengan bangunan purbakala. Oleh karena tidak mendapat perhatian, wajar jika salah dalam pemeliharaan, terutama yang terkait dengan prinsip-prinsip kepurbakalaan.
Bagaimana dengan model konvensional yang kita lakukan sejauh ini? Bisa jalan, tetapi jika tidak ada gayung bersambut, maka kekuatan menjadi timpang dan jalannya menjadi lambat, bahkan menjadi macet. Hal ini tercermin dari pengelolaan Situs Kubur Tajau dan bangunan kolonial di Sanga Sanga, Gua prasejarah di Kabupaten Tabalong, dan Situs Patih Muhur, Barito Kuala, Kalimantan Selatan. Situs Kubur Tajau dan bangunan kolonial di Sanga Sanga, upaya pengelolaannya dimulai dengan rencana pembebasan tanah dan registrasi, awalnya berjalan lancar. Akan tetapi, dalam perkembangannya keduanya menemui hambatannya masing-masing. Pembebasan tanah untuk Situs Kubur Tajau gagal. Pihak Dinas Kebudayaan dan Pariwisata Kabupaten Kutai Kertanegara yang mengusulkan merasa tidak tahu apa penyebab kegagalan tersebut. BP3 Samarinda sejauh ini hanya mampu menyelesaikan masalah dengan cara mengangkat salah seorang anak pemilik lahan untuk dijadikan sebagai juru pelihara Situs Kubur Tajau. Sementara itu, BP3 Samarinda yang bekerja sama dengan Dinas Kebudayaan dan Pariwisata Kutai Kertanegara untuk urusan registrasi benda cagar budaya, hanya berhenti sampai di situ. Belum ada tindak lanjut usulan untuk menjadikan BCB. Padahal itu yang merupakan langkah awal sebagai pijakan dalam melakukan koordinasi dalam pengelolaan.

Pengelolaan dalam rangka pemeliharaan terhadap situs gua prasejarah di Kabupaten Tabalong dan Situs Patih Muhur di Kabupaten Barito Kuala, Kalimantan Selatan dalam pengelolaan yang awalnya dilakukan melalui 
Usulan Model Pengelolaan Sumberdaya Budaya:

Pemikiran Berdasarkan Kasus-kasus di Kalimantan 170-194

jalur konvensional pun mengalami hal yang serupa. BKSDA Kalimantan Selatan tidak berhasil dalam upaya menghentikan masyarakat dalam menambang batu-batu di sekitar Situs Gua Babi di Tabalong. Balai Arkeologi Banjarmasin yang mencoba menggandeng Dinas Kebudayaan dan Pariwisata setempat pun hanya seperti seremonial dan setelah itu tidak ada pengaruh yang berarti untuk bisa menghentikan kegiatan pertambangan batu tersebut. Sejauh ini untuk Tabalong belum pernah masuk ke pemberitaan media massa.

Sementara itu, untuk Situs Patih Muhur di Barito Kuala sebenarnya telah diawali dengan pemberitaan media masa, bahkan tingkat nasional. Akan tetapi, tidak ada tindak lanjut yang nyata untuk urusan pelestarian situs tersebut. Baik yang bersifat pemberdayaan masyarakat, aksi langsung terhadap pelestarian situs, maupun upaya pembebasan tanahnya. Ketiadaan tindak lanjut dan ketiadaan kontrol dari media massa menjadikan kegiatan kepurbakalaan di situs tersebut berhenti dan tidak ada arah yang jelas hingga kini. Dalam hal ini tampaknya kesinambungan pelestarian itu sendiri kurang tergarap.

Secara teknis, dalam implementasi pelestarian, betul seperti yang dikatakan Daud Aris Tanudirjo, yaitu memberi peluang akan adanya pemaknaan baru oleh masyarakat. Adanya pemaknaan baru bisa terjadi jika situs berada dalam konteks sistem masyarakat. Dengan demikian, salah satu cara untuk pelestarian adalah mengkontekssistemkan

Skema 1. Alur pengelolaan dan pelestarian SDB

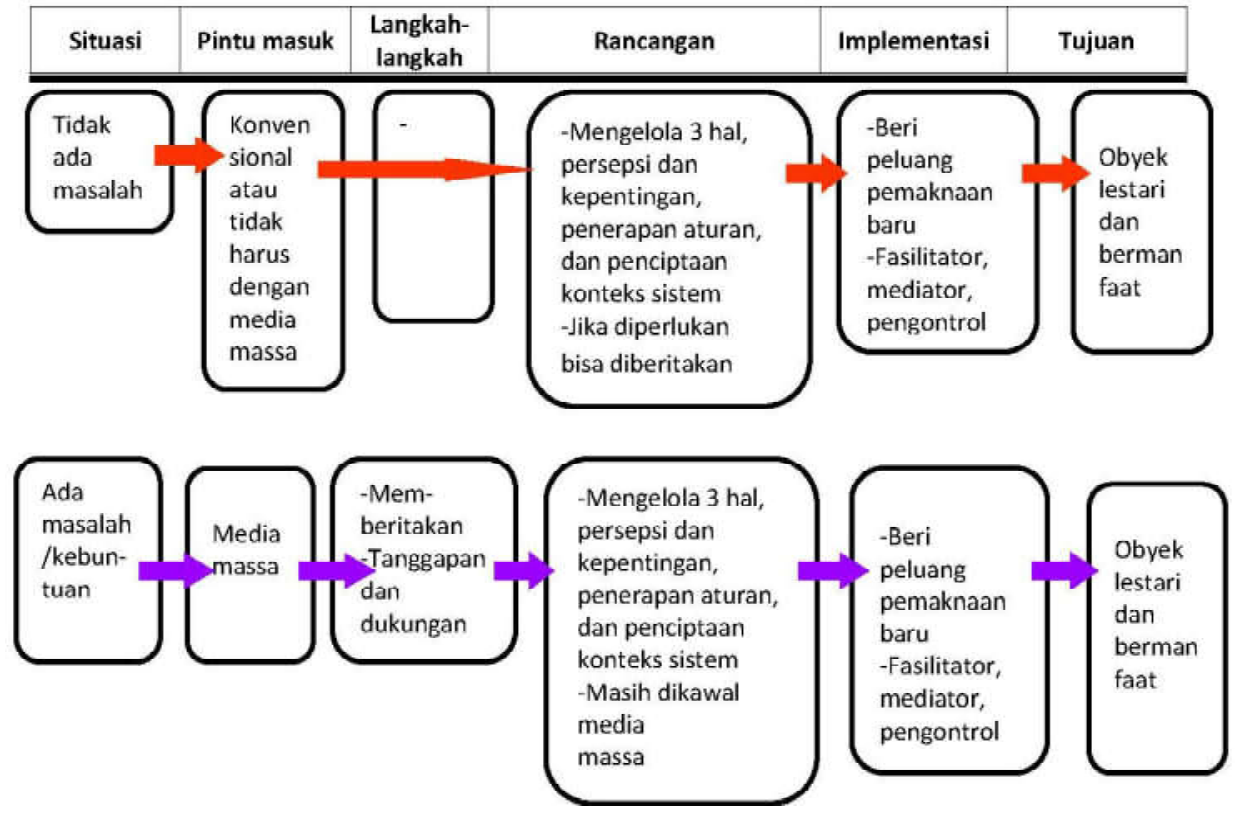

Gambar 1. Alur pengelolaan dan pelestarian SDB 
situs. Namun setelah sampai di sini penulis memiliki pendapat yang sedikit beda, dalam hal ini arkeolog jangan hanya menempati posisi sebagai fasilitator dan juga mediator, tetapi arkeolog hendaknya bersikap fleksibel (Gambar 1). Pada saat tertentu boleh menempatkan diri sebagai fasilitator dan mediator, tetapi pada saat dibutuhkan arkeolog harus bisa bersikap sebagai pengontrol (Wasita 2011a).

Konteks sistem suatu situs memiliki dua sifat, yaitu mendukung dan tidak mendukung pelestarian. Bagi situs yang memiliki/ menempati keterkaitan yang sedikit dengan sistem kehidupan masyarakat, maka jika konteks sistemnya mendukung pelestarian, berarti sifat terlestarikannya situs juga tidak terlalu besar, sebab konteks dan peran situs dengan kehidupan masyarakat tidak besar. Berbeda halnya jika situs menempati keterkaitan yang besar dengan sistem kehidupan masyarakat dan bersifat melestarikan, maka situs akan terlestarikan dengan baik oleh masyarakat.

Sebaliknya, jika suatu situs konteks sistemnya tidak terlalu besar dan bersifat tidak mendukung pelestarian, maka situs akan lebih lestari karena tidak mendapat gangguan dari aktivitas masyarakat, sedangkan pada situs dengan keterkaitan dengan masyarakat yang begitu besar tetapi bersifat tidak mendukung pelestarian maka akan lebih cepat terjadi kerusakan karena aktivitas manusia. Oleh karena itu, cagar budaya dalam posisi yang kurang terlestarikan perlu campur tangan arkeolog. Cara yang dilakukan adalah dengan mengkontekssistemkan dan membentuk kondisi-kondisi yang mendukung. Lebih jauh alur pemikiran tersebut bisa dilihat pada gambar berikut (gambar 2).

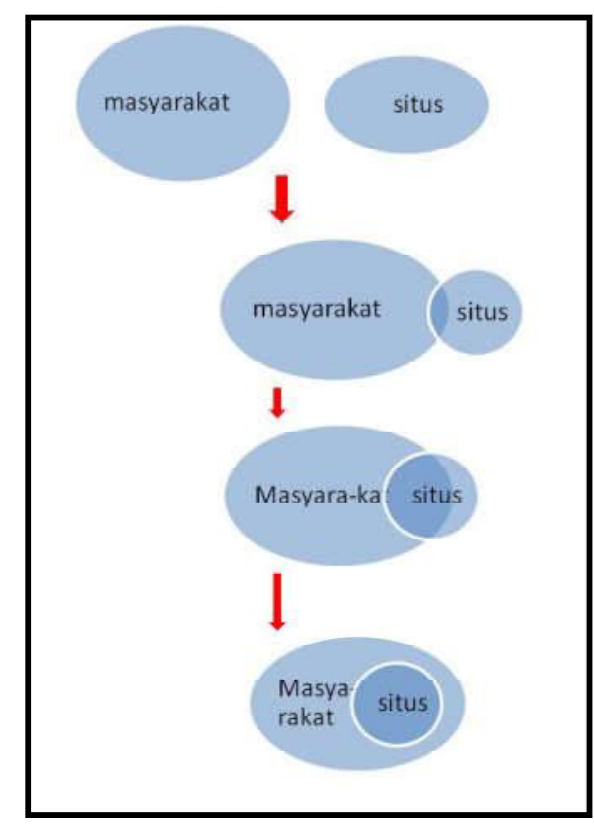

Gambar 2. Skema upaya memasukkan situs ke dalam konteks sistem masyarakat

Maksud dari gambar tersebut adalah jika terdapat situs yang belum berada dalam konteks sistem, maka diupayakan agar masuk dalam konteks sistem masyarakat. Setelah hal itu terjadi upayakan agar tidak sekedar masuk, tetapi menjadi bagian terbesar dalam sistem kehidupan mereka. Tujuan dari itu semua adalah agar situs menjadi bagian yang tidak terpisahkan dalam kehidupan dan menempati posisi yang penting dan mereka merasa tidak mungkin akan merusaknya.

Namun demikian, diakui juga bahwa pemanfaatan situs oleh masyarakat juga ada yang bersifat tidak baik dalam kaitannya dengan pelestarian. Dalam posisi ini, maka yang diperlukan adalah peran arkeolog untuk membentuk konteks sistem yang mendukung pelestarian. Dalam hal ini, arkeolog sebagai 
Usulan Model Pengelolaan Sumberdaya Budaya:

Pemikiran Berdasarkan Kasus-kasus di Kalimantan 170-194

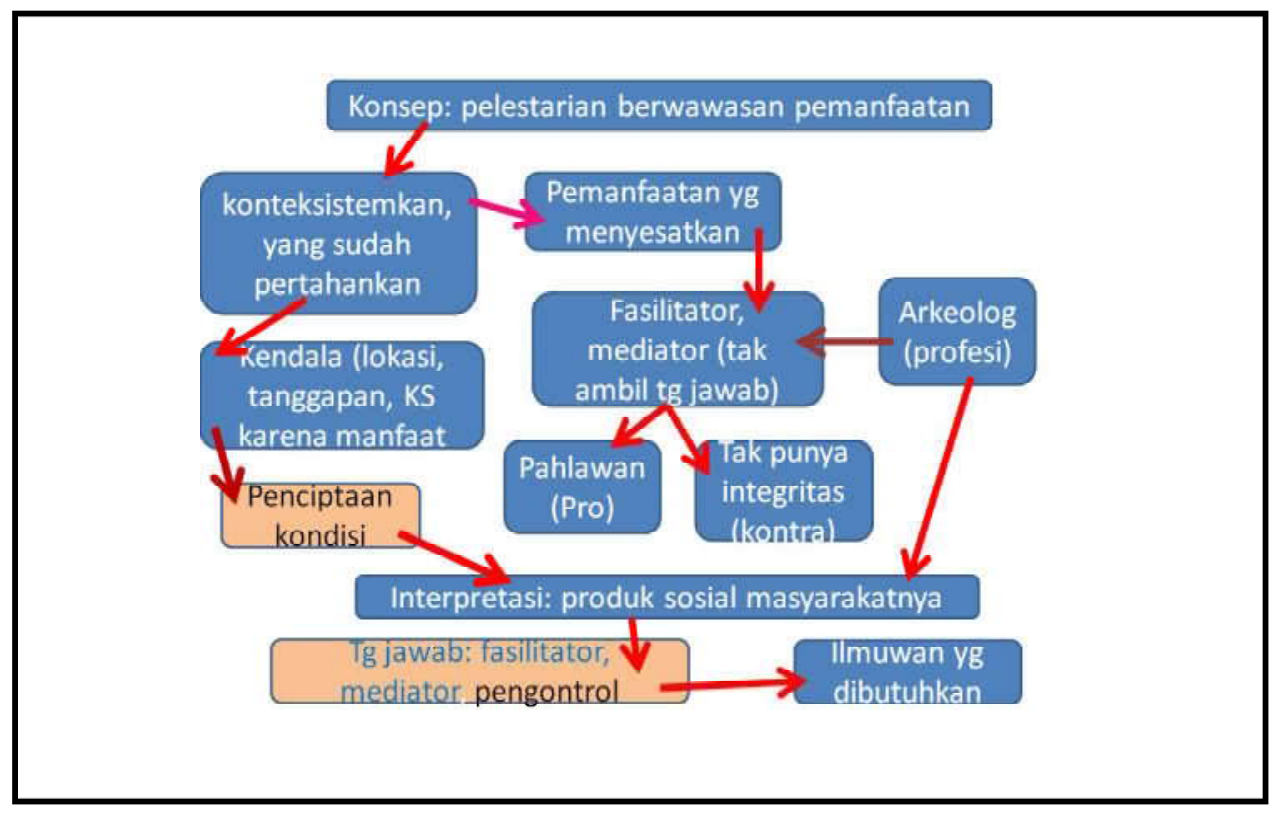

Gambar 3. Alur pikir pengelolaan situs, warna pink, model yang diusulkan penulis

profesi hendaknya bersikap mengambil tanggung jawab atas hasil kerjanya. la jangan terus-menerus memfasilitatori jika pemanfaatan situs oleh masyarakat kurang mendukung pelestarian. Sebaliknya, dengan mengambil tanggung jawab keprofesiaannya, dalam kondisi situs kurang terlestarikan, ia harus berani menempatkan diri sebagai pengontrol. Tujuannya selain untuk menciptakan kondisi terlestarikannya situs maka dalam kesempatan tertentu juga untuk memberikan pencerahan kepada masyarakat. Dalam hal ini interpretasi sebagai produk arkeolog yang juga dipengaruhi oleh kehidupan sosialnya perlu pertanggungjawaban. Jika demikian sikap yang diambil oleh arkeolog, mudah-mudahan masyarakat akan merasa mendapat manfaat atas keberadaan kita. Jika mereka bisa merasakan yang demikian ini diyakini arkeolog dan arkeologi akan lebih diperlukan lagi kehadirannya di masyarakat (gambar 3).

Dalam prakteknya, arkeolog harus bisa mengambil peluang yang ada untuk memaksimalkan upaya pelestarian situs. Dimulai dari aturan main dalam pengelolaan, penyuluhan untuk membekali pengetahuan kepurbakalaan, kemudian masuk ke pemberdayaan seperti yang disampaikan Bambang Sulistyanto, dari sini diharapkan pelan-pelan akan mengarahkan persepsi para pemangku kepentingan dari yang tidak mendukung pelestarian menjadi mendukung, dan akhirnya jika mereka sudah siap maka terakhir situs bisa dikonteksistemkan dalam kehidupan mereka, misal sebagai Kota Wisata Juang untuk tinggalan kolonial Sanga Sanga. 
Usulan Model Pengelolaan Sumberdaya Budaya:

Dalam hal ini urutan pelaksanaannya tidak harus sama, yang penting isi dari semua itu terpenuhi. Tampaknya benang merah dari semua itu adalah memahamkan aturan tentang pelestarian, sehingga mengarahkan persepsi para stakeholder agar mendukung pelestarian, dan setelah semuanya siap, maka situs dapat segera dikontekssistemkan dalam kehidupan mereka.

\section{Penutup}

Di sini usulan penulis tentang pengelolaan SDB lebih ditekankan pada strategi untuk menentukan pintu masuk dalam pelaksanaan pengelolaan. Strategi pemilihan pintu masuk tersebut dianggap perlu sebagai langkah awal pengelolaan yang sejauh ini kurang mendapat perhatian. Padahal bagian tersebut merupakan penentu untuk kelancaran langkah-langkah berikutnya.

Dalam hal ini pilihan kepada jalur konvensional atau media massa ditentukan oleh kondisi lapangan. Sebenarnya, pilihan terhadap jalur yang manapun akan sampai pada jalur konvensional. Di tingkat implementasi, hasil evaluasinya diketahui bahwa pengeloaan SDB dilakukan melalui pengelolaan persepsi dan kepentingan stakeholder, penerapan aturan yang terkait dengan rambu-rambu pengelolaan, dan penciptaan konteks sistem yang mendukung pelestarian. Dalam hal ini persepsi merupakan landasan stakeholder/pemangku kepentingan situs dalam keikutsertaannya menjalankan pengelolaan. Penerapan aturan dalam pengelolaan merupakan dasar bagi pemangku kepentingan dari pihak pemerintah sebagai pengelola kepurbakalaan, konteks sistem sendiri merupakan situsasi yang terjadi dengan sendirinya atau bentukan yang diharapkan masuk ke dalam sistem yang dikembangkan masyarakat yang melibatkan situs/bangunan purbakala dan bersifat melestarikan.

Dalam implementasi pelestarian tersebut, penulis sepakat dengan yang dilontarkan oleh penulis-penulis sebelumnya, yaitu agar lestari dan murah dalam pembiayaannya situs harus dimasukkan ke dalam konteks sistem masyarakat. Agar bisa mengambil manfaat yang sebesar-besarnya, masyarakat perlu diberdayakan. Dan supaya sesuai dengan dinamika kehidupan, maka masyarakat berkesempatan memberi makna baru atas situs yang ada di lingkungannya. Dalam posisi ini, arkeolog harus bisa menjadi fasilitator dan mediator. Namun jangan hanya berhenti di situ. Akan lebih baik jika arkeolog mengambil sikap fleksibel, yaitu bisa sebagai fasilitator dan mediator, tetapi bisa juga sebagai pengontrol.

Posisi ini diperankan semata-mata untuk memperjuangkan arkeolog dan ilmunya agar bermanfaat untuk masyarakat dalam meraih kehidupan yang lebih baik. Upaya tersebut perlu diperjuangkan karena dalam posisi tersebut arkeolog tidak hanya melayani masyarakat dan menyediakan SDB sebagai obyek untuk kepentingan mereka, tetapi arkeologi dan arkeolognya harus bisa berperan sebagai pengontrol agar masyarakat dapat memanfaatkannya dengan cara benar. Di sinilah arkeolog tidak hanya melayani, tetapi juga menjadi penunjuk jalan yang dibutuhkan masyarakat. 
Usulan Model Pengelolaan Sumberdaya Budaya:

Pemikiran Berdasarkan Kasus-kasus di Kalimantan 170-194

\section{Referensi}

Daud, Alfani. 1997. Islam dan masyarakat Banjar deskripsi dan analisa kebudayaan Banjar. Jakarta: PT. Raja Grafindo Persada.

Gunadi. 2005. Situs Candi Agung dan permasalahannya. Dalam Seminar sehari, Candi Agung dan Penangannya. Amuntai, 18 april 2005. Tidak terbit.

Ismiyono. 2005. Prinsip-prinsip pelestarian kawasan benda cagar budaya.

Nimpoeno, S. J. 1980. Fungsi warisan sebagai pembentuk sikap terhadap pembangunan. Dalam Analisis Kebudayaan I (1): 2631.

Noerwidi, Sofwan. 2007. Pemberdayaan masyarakat pada pelestarian Situs Bangkai Kapal "USS Liberty", Tulamen, Bali. Berkala Arkeologi. Yogyakarta: Balai Arkeologi Yogyakarta.

Riyanto, S. 2008. Kerangka pengembangan Situs Candi Losari: kajian awal untuk pengembangan penelitian, pendidikan, dan kepariwisataan. Berkala Arkeologi XXVIII (1): 46-56.

Tanudirjo, Daud Aris. 2000. "Reposisi arkeologi dalam era global. Dalam Bulletin Cagar Budaya 1 (2): 11 26.

2004. Pengelolaan sumberdaya arkeologi: sebuah pengantar. Dalam Pelatihan Sumberdaya Arkeologi di
Trowulan, 27 Agustus - 1 September 2004. Tidak terbit.

Tim Penelitian. 2008. "Permukiman dan industri pertambangan: pengaruh Kolonial di Kalimantan Timur. Laporan Penelitian Arkeologi. Jakarta: Pusat Penelitian dan Pengembangan Arkeologi Nasional. Belum terbit.

Tim Penelitian. 2010. Laporan inventarisasi tinggalan Kolonial di Kabupaten Kutai Kertanegara, Kalimantan Timur. Samarinda: Dinas Kebudayaan dan Pariwisata Kabupaten Kutai Kertanegara dan Balai Pelestarian Peninggalan Purbakala.

Sulistyanto, Bambang. 2009. Warisan dunia Situs Sangiran: persepsi menurut penduduk Sangiran. Wacana. Jakarta: Universitas Indonesia. HIm. 57-80.

Susanto, Nugroho Nur. 2009. 2005. Penelitian aspek keruangan pola tatakota Kolonial Sanga Sanga di Kabupaten Kutai Kertanegara, Provinsi Kalimantan Timur. Laporan Penelitian Arkeologi. Banjarbaru: Balai Arkeologi Banjarmasin. Belum terbit.

Wasita. 2010. Perbedaan persepsi tentang Candi Agung: indikasi pemasyarakatan arkeologi belum diadopsi. Jejak-Jejak Arkeologi. Manado: Balai Arkeologi Manado. 
Usulan Model Pengelolaan Sumberdaya Budaya: Pemikiran Berdasarkan Kasus-kasus di Kalimantan 170-194

(bub)perspekif 2011a. Penambahan
mengefektifkan pemanfaatan
tinggalan arkeologi. Pertemuan
IImiah Arkeologi, Surabaya, 1-3
November 2011. Belum terbit.
Muslim dalam pemanfaatan
Situs Candi Agung di Amuntai,
Kalimantan Selatan. Tesis.
Yogyakarta: Program Studi
Antropologi Universitas Gadjah
Mada.

Sulistyanto, Bambang. 2011a. Konflik dalam pengelolaan sumberdaya arkeologi. Diakses dari http:// hurahura.wordpress.com/2011/ $07 / 05 / \mathrm{k}$ onflik-dalampengelolaan-sumberdayaarkeologi/

Sulistyanto, Bambang. 2011. Pemberdayaan masyarakat di lingkungan situs arkeologi.Diakses dari http:// hurahura.wordpress.com/2011/ $07 / 08 /$ pemberdayaanmasyarakat-di-lingkungan-situsarkeologi/ 